\title{
Australian Journal of Crop Science \\ Growth and mineral nutrition of mahogany (Swietenia macrophylla) seedlings subjected to lime in Yellow Alic Latosol
}

\section{George Rodrigues da Silva ${ }^{1}$, Ismael de Jesus Matos Viégas²*, Mário Lopes da Silva Júnior ${ }^{1}$, Marcos André Piedade Gama ${ }^{1}$, Ricardo Shigueru Okumura ${ }^{2}$, Dilson Augusto Capucho Frazão ${ }^{3}$, Gilson Sérgio Bastos de Matos ${ }^{1}$, João Cardoso de Souza Júnior ${ }^{1}$, Eduardo do Valle Lima ${ }^{2}$, Jessivaldo Rodrigues Galvão ${ }^{1}$}

\author{
${ }^{1}$ Instituto de Ciências Agrárias, Universidade Federal Rural da Amazônia, Tancredo Neves avenue, 2501, CEP \\ 66077-580, Belém city, Brazil \\ ${ }^{2}$ Capanema campus, Universidade Federal Rural da Amazônia, Capanema city, Brazil \\ ${ }^{3}$ Federação da Agricultura do estado do Pará, Belém city, Brazil
}

*Corresponding author: ismael.viegas@ufra.edu.br

\begin{abstract}
The management practices of soil fertility, such as use of lime on mahogany (Swietenia macrophylla King.) nutrition contribute to the crop yield especially in acidic soils. The main aim of this study was to evaluate the application of lime in early growth and nutrient uptake in mahogany seedlings. The treatments were limestone rates $\left(0,1.9,3.2\right.$, and $\left.4.6 \mathrm{tha}^{-1}\right)$ necessary to increase the base saturation of substrate (currently 12.4\%) for 20,40,60 and 80\%, respectively, with five replications arranged in a randomized design. The variables evaluated were: plant height, stem diameter, root dry matter, shoot dry matter and total dry matter and N, P, K, Ca, and $\mathrm{Mg}$ concentration in shoots. Through this, accumulation of nutrients was estimated. Different lime rates positively influenced the vegetative growth of mahogany seedling. The maximum technical efficiencies for stem diameter of $1.40 \mathrm{~cm}$; root dry matter of 28.61 $\mathrm{g}$ plant ${ }^{-1}$; shoot dry matter of $80.25 \mathrm{~g}$ plant $^{-1}$; total dry matter of $107.16 \mathrm{~g} \mathrm{plant}^{-1}$; and shoot/root ratio of 2.92 were achieved at rates of $3.33 ; 4.54 ; 4.56 ; 4.58$; and $3.82 \mathrm{tha}^{-1}$, respectively. Regarding the nutrient concentrations in aerial part of plant, we observed that $\mathrm{N}$ $\left(23.14 \mathrm{~g} \mathrm{~kg}^{-1}\right) ; \mathrm{P}\left(4.43 \mathrm{~g} \mathrm{~kg}^{-1}\right) ; \mathrm{K}\left(13.04 \mathrm{~g} \mathrm{~kg}^{-1}\right)$; Ca $\left(4.25 \mathrm{~g} \mathrm{~kg}^{-1}\right)$; and $\mathrm{Mg}\left(3.37 \mathrm{~g} \mathrm{~kg}^{-1}\right)$ concentration were obtained at rates of 2.88 ; $3.20 ; 3.31 ; 3.64$; and $2.93 \mathrm{tha}^{-1}$, respectively. Some nutritional requirements were observed in mahogany culture in soil with acidity correction. The nutrient accumulation values were observed according to following descending order: $\mathrm{N}>\mathrm{Ca}>\mathrm{K}>\mathrm{Mg}>\mathrm{P}$. In general, for initial development of mahogany we observed that best results, either biometric as a nutritional, were obtained at rates between 2.74 to $3.64 \mathrm{t} \mathrm{ha}^{-1}$ of lime application.
\end{abstract}

Keywords: forest specie, lime, nutrient uptake, substrate.

Abbreviations: N_nitrogen, P_phosphorus, K_potassium, Ca_calcium, Mg_magnesium, SB_sum of bases values, CEC_cation exchange capacity, V\%_base saturation.

\section{Introduction}

Mahogany (Swietenia macrophylla King), which belongs to Meliaceae family, is a semi-deciduous or deciduous tree species, predominantly tropical, commonly found in mainland forests of Brazilian Amazon. The high demand for mahogany wood is because of its easy carpentry work and exceptionally smooth, shiny and resistant surface. This motivates farmers to grow this species in natural extensions in recent years (Santos et al., 2008). However, there is a risk of extinction because no enough renewal of stocks occurs in the same proportion after resource exploitation.

According to Tucci et al. (2009), the environmental problems resulting from disorderly extractivism and commercial value of wood has promoted a significant increase in mahogany cultivation. However, most of trees are grown isolated or intercropped, which does not prosper the species renewal mainly due to problems related to growth conditions and seedling quality. The quality of seedlings is directly related to quality of substrate, because it depends on whole set of events that involve and precede its production. Among the main morphological parameters that define seedling quality, the plant height, stem diameter, height and stem diameter ratio and total dry matter mass are highlighted. The physiological parameters include the water potential and nutritional status of seedlings (Tucci et al., 2007). Important aspects in cultivation of tree species seedling stage should be observed, mainly related to knowledge of nutritional requirements. Study of nutritional deficiencies of mahogany grown on degraded substrates enables better nutritional soil correction during formation of seedlings to field, a period of great ecological and economic importance for forestry programs (Sarcinelli et al., 2004). For production of quality seedlings, it is necessary to know characteristics of species, particularly their nutritional requirements and their responses to correction of substrate, in which subsoil is commonly used by small farmers (Walker et al., 2011). However, the substrate originated from subsurface soil is usually acidic (Tucci et al., 2009) associated with the characteristics of Amazon soils of low fertility (Vale Júnior et al., 2011). In these acidic soils, the chemical properties are predominantly dependent on soil pH (Neves Neto et al., 2012). Application 
of lime is essential for nutritional correction of substrate in formation process of seedlings (Silva et al., 2007), since it contributes for reducing acidity and neutralizing effect of toxic elements (Alleoni et al., 2010), besides favoring increase in availability of most nutrients required by crops (Araújo et al., 2009).

Despite Amazonian species are more rustic and adapted to conditions of high acidity and low nutrient availability, reduction of chemical limitations promote better plant growth (Silva et al., 2007; Laviola and Dias, 2008). Assessment of chemical characteristics that improves productivity of plant is very crucial. The quantification of nutrients in different parts of plant generates guide information about rates of fertilizers and corrective which should be applied for better productivity.

Application of lime rates in low fertility soil on growth and nutrient uptake of mahogany, Silva et al. (2007) observed that liming positively affected the growth in stem diameter, dry matter and macronutrients uptake with maximum efficiency technique obtained at a rate of $2.5 \mathrm{tha}^{-1}$ of lime.

Thus, research to identify the effects of soil acidity correction and nutrient enhancement on mahogany development is indispensable and urgent. The aims of study were to evaluate effects of liming on growth and macronutrients uptake by mahogany seedlings, as well as establishing a rate of liming appropriate for optimal development, contributing to knowledge of nutritional requirement of plant in Brazilian Amazon. The research is justified by the fact that soil acidity has limited plant growth in tropical soils and behavior in early development of seedlings has been influenced by degree of soil acidity.

\section{Results and Discussion}

\section{Chemical characteristics of substrate soil before application of treatments}

Results presented in Table 1 showed that soil used as substrate had $\mathrm{pH}$ of 4.1 , demonstrating a strong acid soil (Silva et al., 2006), with high concentration of $\mathrm{Al}^{3+}$ and low value of sum of bases, resulting in very high aluminum saturation and low base saturation. The low fertility associated with low-P, usually observed in Oxisols of the Amazon region (Silva et al., 2007; Vale Júnior et al., 2011).

\section{Effects of liming on vegetative growth}

Stem diameter (SD) of mahogany seedlings was significantly influenced by rates of limestone, presenting quadratic equation $\left(\hat{\mathrm{Y}}=1.07+0.20 \mathrm{X}-0.03 \mathrm{X}^{2}, \mathrm{R}^{2}=0.99\right)$. The quantity of lime to be applied for the maximum technical efficiency was $3.33 \mathrm{tha}^{-1}$ to achieve $1.40 \mathrm{~cm}$ of SD (Fig 1a).

Increase in stem diameter of mahogany seedlings in response to application of lime was observed by Silva et al. (2007) at rate of $2.5 \mathrm{t} \mathrm{ha}^{-1}$. This rate showed higher nutrient concentrations in shoot $(33.64 ; 2.90 ; 35.77 ; 17.81 ;$ and $2.02 \mathrm{~g}$ plant $^{-1}$ to N, P, K, Ca, and $\mathrm{Mg}$, respectively).

Results obtained for plant height presented linear regression model $\left(\hat{\mathrm{Y}}=47.49+7.27 \mathrm{X}, \mathrm{R}^{2}=0.98\right)$ which is referred to plant biomass, shoot dry matter, quadratic models $\left(\hat{\mathrm{Y}}=25.50+24.00 \mathrm{X}-2.63 \mathrm{X}^{2}, \mathrm{R}^{2}=0.99\right)$, root dry matter $(\hat{\mathrm{Y}}$ $\left.=19.11+4.18 \mathrm{X}-0.46 \mathrm{X}^{2}, \mathrm{R}^{2}=0.90\right)$, and total dry matter $(\hat{\mathrm{Y}}$ $\left.=44.93+27.19 \mathrm{X}-2.97 \mathrm{X}^{2}, \mathrm{R}^{2}=0.98\right)$, indicating that there were positive response to increase rates of lime applied to the soil (Fig 1).

From Fig 1b, we observed increase in plant height of 27.7 $\mathrm{cm}$ per ton of limestone applied in the soil, until a maximum rate of $4.6 \mathrm{t} \mathrm{ha}^{-1}$, which resulted in $\mathrm{PH}$ of $80.93 \mathrm{~cm}$. Similar results were obtained by Bernadino et al. (2005), who studied Anadenanthera macrocarpa seedlings developed in Latosol, and observed linear response to lime rates $(\hat{\mathrm{Y}}=14.13+$ $0.4847 X, R^{2}=0.99$ )

Contrary to this study, Pedroso et al. (2012) observed that application of up to $2.0 \mathrm{t} \mathrm{ha}^{-1}$ of lime did not affect plant height of mahogany seedling in Yellow Latosol. Increase in $\mathrm{PH}$, possibly be related to an improvement in $\mathrm{P}$ utilization efficiency providing increased aerial part of plant (Maeda and Bognola, 2011).

Liming at rates of $4.54,4.56$, and $4.58 \mathrm{t} \mathrm{ha}^{-1}$ provided maximum technical efficiency for root dry matter (Fig 1c); shoot dry matter (Fig 1d); and total dry matter (Fig 1e), corresponding to $28.61 ; 80.25$; and $107.16 \mathrm{~g} \mathrm{plant}^{-1}$, respectively. Silva et al. (2007) observed a positive effect of limestone rates in stem diameter, root dry matter, shoot dry matter, and total dry matter of mahogany seedlings.

For shoot/root ratio (Fig 1f) a quadratic model ( $\hat{Y}=1.32+$ $\left.0.84 \mathrm{X}-0.11 \mathrm{X}^{2}, \quad \mathrm{R}^{2}=0.99\right)$ with maximum technical efficiency of 2.92 was obtained at a rate of $3.82 \mathrm{t} \mathrm{ha}^{-1}$ of limestone, representing a V\% value of approximately $70 \%$. Results of Fig 1 showed positive effect of lime application on distribution of biomass of shoot and root system in mahogany seedlings reported by other authors (Silva et al., 2007; Tucci et al., 2007).

According to Silva et al. (2007), no restriction was occurred during shoots development with increase in lime rates, increasing shoot/root ratio. This fact is reinforced in this study, observing that greatest value of shoot/root ratio (2.92) was $123 \%$ higher than amount provided in absence of lime (1.32) (Fig 1f).

Application of lime has influenced shoot/root ratio of other forest species with different results. Cruz et al. (2004), observed increased shoot/root ratio by liming in ipê-roxo seedlings (Tabebuia impetiginosa (Mart.) Standley), with maximum technical efficiency obtained in $\mathrm{V} \%$ of $71.5 \%$. Sena et al. (2010) observed no effect of liming on shoot/root ratio in angelim-pedra seedlings (Dinizia excels Ducke), suggesting that plants did not develop root system as a mechanism to compensate for absence of limestone.

Positive response of mahogany possibly occurs due to effects caused by lime, by which soil $\mathrm{pH}$ is raised and concentration of toxic aluminum is reduced (Sena et al., 2010). The reduction of aluminum toxicity will increase nutrients availability (Santos et al., 2010), and microbial activity (Arantes et al., 2011). These studies support our results, observing that significant increases in uptake and nutrients accumulation are promoted by liming in substrate.

Several studies have shown positive results of lime application on growth of mahogany seedlings (Tucci et al., 2007; Souza et. al., 2010; Pedroso et al., 2012). Similarly, increased growth with liming was observed in other tree species like kapok (Ceiba pentandra (L.) Gaertn.) (Tucci et al., 2002; Silva et al., 2008), angelim-pedra (Dinizia excels Ducke) (Sena et al., 2010), pau-de-balsa (Ochroma pyramidale (Cav.) Urb.) (Tucci et al., 2010), and ipê-roxo (Tabebuia impetiginosa (Mart.) Standley) (Cruz et al., 2004). By results shown in Fig 1, we verified that liming is an important agricultural practice for forestry, especially in seedling production. Correction of substrate acidity cannot directly benefit the practice, but increases availability of $\mathrm{Ca}^{+2}$ and $\mathrm{Mg}^{+2}$ with greater relevance in formation process of seedlings (Artur et al., 2007; Sena et al., 2010). In some situations, it may enhance beneficial effect of liming by association with phosphorus (Gomes et al., 2008; Silva et al., 
Table 1. Chemical characteristics of soil used as substrate before application of treatments.

\begin{tabular}{|c|c|c|c|c|c|c|c|c|c|c|}
\hline $\mathrm{pH}$ & $\mathrm{P}$ & K & $\mathrm{Ca}^{2+}$ & $\mathrm{Mg}^{2+}$ & $\mathrm{Al}^{3+}$ & $\mathrm{H}+\mathrm{Al}$ & SB & CEC & V & $\mathrm{m}$ \\
\hline$\left(\mathrm{H}_{2} \mathrm{O}\right)$ & $\mathrm{mg} \mathrm{dm}^{-3}$ & -- & 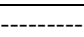 & $\mathrm{cmol}_{\mathrm{c}} \mathrm{c}$ & ")-- & ------- & & & ------ & \\
\hline 4.1 & 3.0 & 0.03 & 0.6 & 0.2 & 1.1 & 5.86 & 0.83 & 6.69 & 12.4 & 57.0 \\
\hline
\end{tabular}

SB: sum of bases; CEC: cation exchange capacity at $\mathrm{pH} 7.0$; V\%: base saturation; $\mathrm{m} \%$ : aluminum saturation.
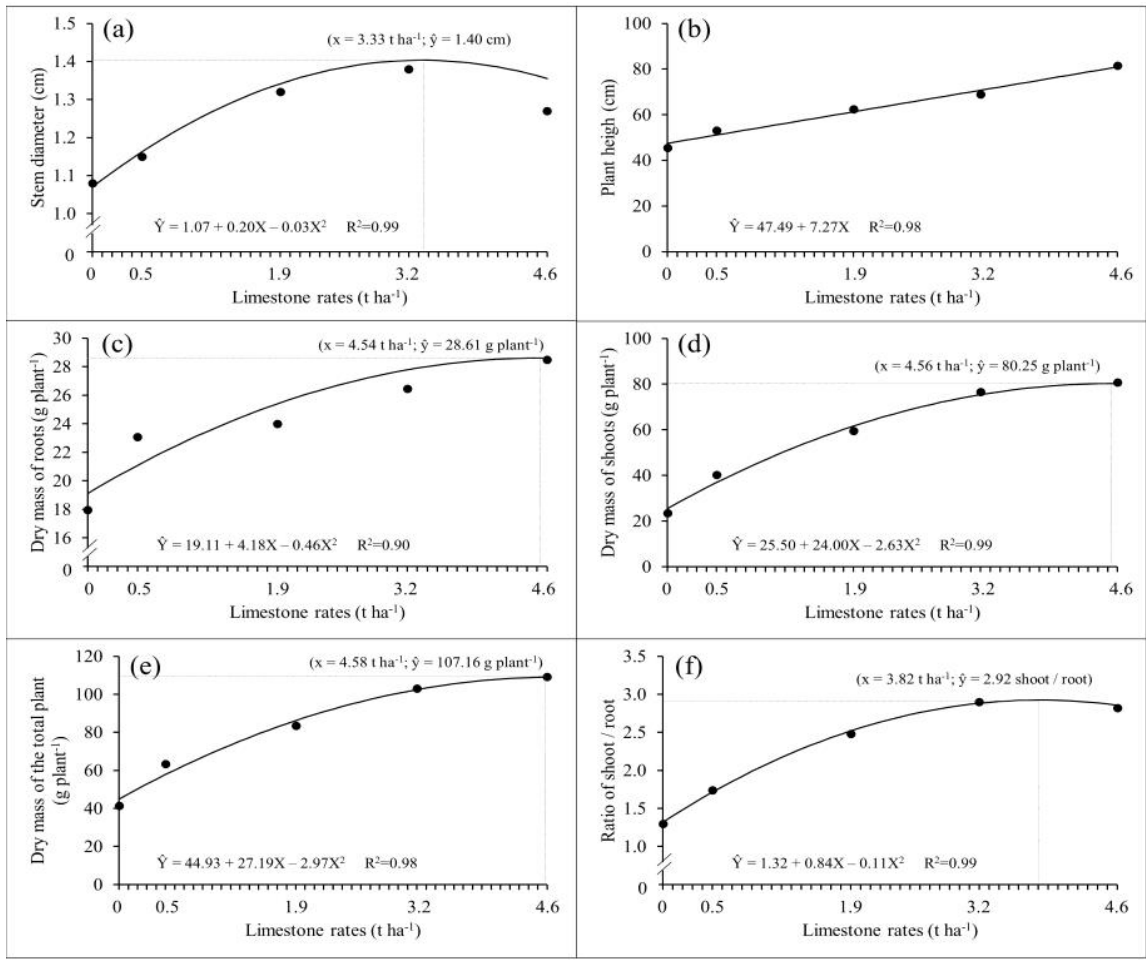

Fig 1. Regression equations adjusted to stem diameter (a); plant height (b); root dry matter (c); shoot dry matter (d); total dry matter (e); and ratio shoot/root (f) in mahogany seedlings subjected to lime rates.

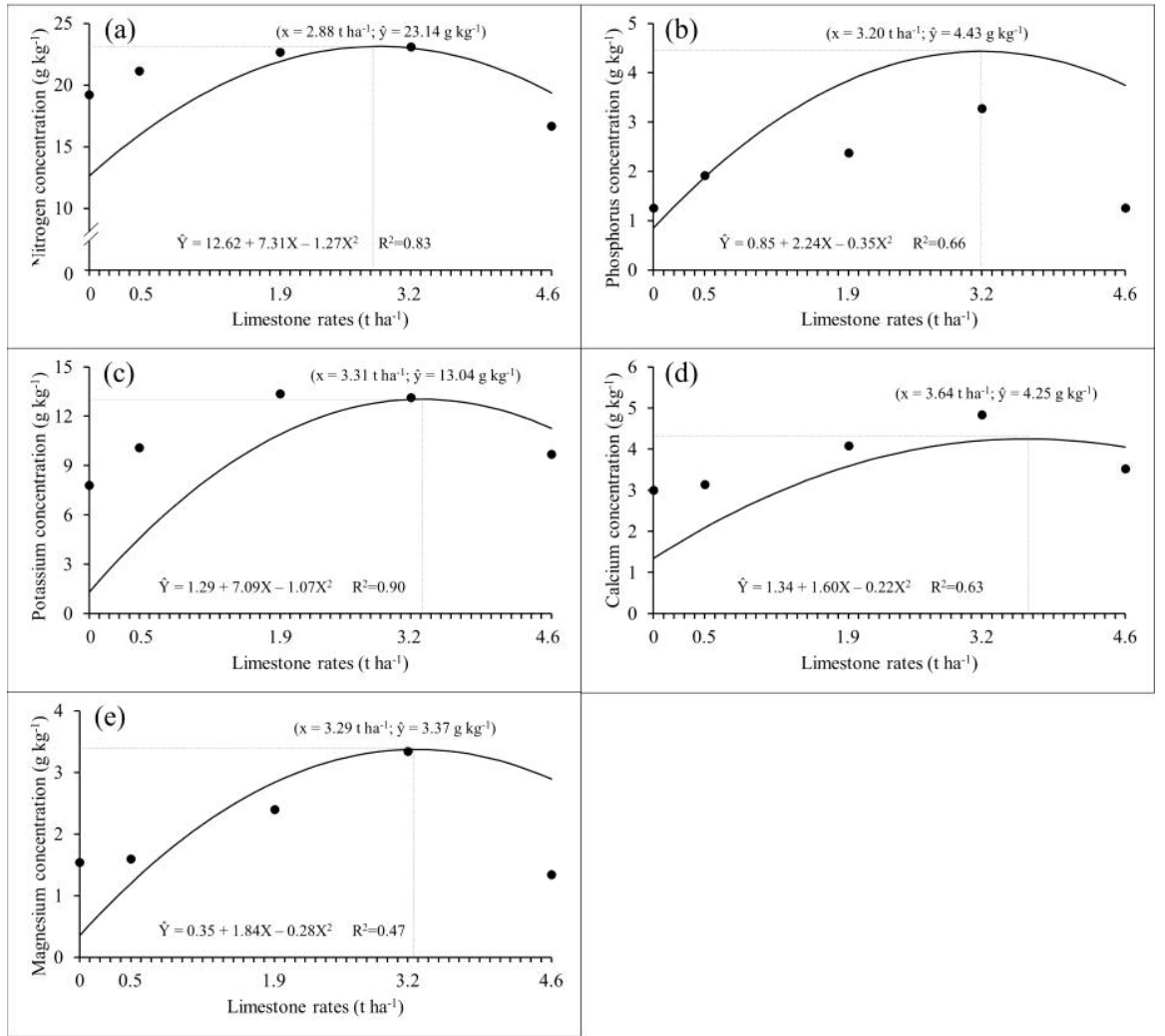

Fig 2. Regression equations adjusted for $\mathrm{N}$ (a) $\mathrm{P}$ (b), $\mathrm{K}$ (c), Ca (d), and $\mathrm{Mg}$ (e) concentrations in shoots of mahogany seedlings subjected to lime rates. 


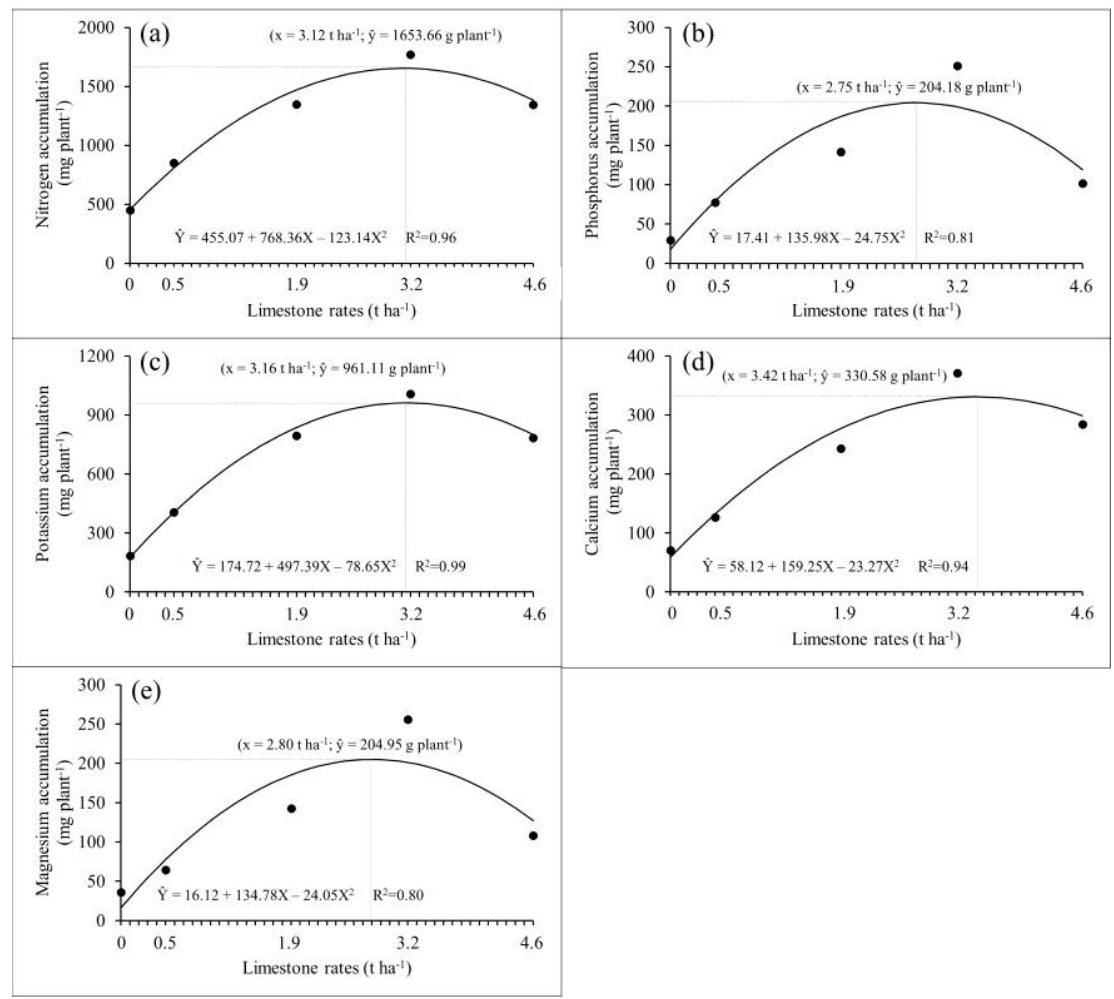

Fig 3. Regression equations adjusted for accumulation of $\mathrm{N}$ (a) P (b), $\mathrm{K}$ (c), Ca (d), and Mg (e) in shoots of mahogany seedlings subjected to limestone rates.

2011), NPK (Tucci et al., 2007), and micronutrient boron fertilizer (Pedroso et al., 2012).

This study has shown the need for research that increases knowledge about action of liming in growth of mahogany seedlings in acid soils and other low fertility soils such as Brazilian Amazon.

Macronutrients uptake in mahogany promoted by application of dolomitic limestone

$\mathrm{N}, \mathrm{P}, \mathrm{K}, \mathrm{Ca}$, and $\mathrm{Mg}$ concentration in shoots of mahogany seedlings showed quadratic regression models (Fig 2), reinforcing results shown in Fig 1, in which application of lime in substrate increased nutrient uptake promoting growth and increase in production of dry matter of plant. This suggests that liming positively influences mahogany development.

Maximum absorption efficiency of $\mathrm{N}\left(23.14 \mathrm{~g} \mathrm{~kg}^{-1}\right)$ was obtained at a rates of $2.88 \mathrm{t} \mathrm{ha}^{-1}$ of lime, estimated by equation, $\hat{\mathrm{Y}}=12.62+7.31 \mathrm{X}-1.27 \mathrm{X}^{2}, \mathrm{R}^{2}=0.83$ (Fig 2a). The positive effect of lime is possibly attributed to increase of $\mathrm{pH}$ and addition of $\mathrm{Ca}$ and $\mathrm{Mg}$, increasing microbial activity and consequently the mineralization of N (Silva et al., 2008).

Maximum estimated concentration of $\mathrm{P}$ in shoots was 4.43 $\mathrm{g} \mathrm{kg}^{-1}$ at a rates of $3.20 \mathrm{t} \mathrm{ha}^{-1}$ of lime (Fig 2b), higher than range of 1.0 to $2.3 \mathrm{~g} \mathrm{~kg}^{-1}$, considered appropriate for forest species (Malavolta et al., 1997). Increase in P uptake due to liming is shown in several studies (Fernandes et al., 2007; Silva et al., 2007, 2008; Macedo and Teixeira, 2012).

$\mathrm{P}$ concentration showed a better adjustment of quadratic equation $\left(\hat{\mathrm{Y}}=0.85+2.24 \mathrm{X}-0.35 \mathrm{X}^{2}, \mathrm{R}^{2}=0.66\right)$, observing improvement in concentrations according to increase in liming, and posteriorly, reduction in concentrations promoted by application of high rates. In first case, limestone rates increased $\mathrm{P}$ availability in acid soils due to increase in soil
$\mathrm{pH}$, since this condition causes precipitation of $\mathrm{Al}$ and $\mathrm{Fe}$ solution and reduction of maximum adsorption capacity of phosphate ions (Camargo et al., 2010).

In acid soils such as Brazilian Amazon (Silva et al., 2007; Vale Júnior et al., 2011), liming is a strategy to increase the $\mathrm{P}$ availability (Novais et al., 2007), since with increase of $\mathrm{pH}$ hydrolysis of minerals occurs. This promotes release of phosphate ions in the soil solution; thus, increase in negative charges on surface of soil particles, resulting in increased electrostatic repulsion (lower adsorption) between phosphate and adsorbent surface. This reduces maximum adsorption capacity of P (Camargo et al., 2010). However, the excess of limestone causes $\mathrm{P}$ precipitation in form of calcium phosphate insoluble (Tirloni et al., 2009), decreasing its availability, as well as other nutrients to plants.

The $\mathrm{K}$ concentration in shoot was influenced by liming (Fig 2c). The maximum technical efficiency (13.04 $\mathrm{g} \mathrm{kg}^{-1}$ ) was obtained at a rate of $3.31 \mathrm{tha}^{-1}$ of lime. In acidic soils, the $\mathrm{K}$ concentration increased under application of lime, since reaction generated charges that can be occupied by $\mathrm{K}$ (Mauad et al., 2004) according to observed by Silva et al. (2008), and Pedroso et al. (2012) for kapok (Ceiba pentandra (L.) Gaertn.), and mahogany (Swietenia macrophylla), respectively.

The $\mathrm{V} \%$ provided by lime application increased $\mathrm{Ca}$ and $\mathrm{Mg}$ in shoots of mahogany seedlings (Figs 2d, 2e) and caused increase in nutrients of substrate. Different results in paricá seedlings were reported by Marques et al. (2004) (Schizolobium amazonicum), who observed an antagonism between absorption of calcium and magnesium.

Maximum concentrations of $\mathrm{Ca}\left(4.25 \mathrm{~g} \mathrm{~kg}^{-1}\right)$ and $\mathrm{Mg}(3.37$ $\left.\mathrm{g} \mathrm{kg}^{-1}\right)$ in shoots of mahogany seedlings were achieved with applications at rates of 3.64 and $3.29 \mathrm{t} \mathrm{ha}^{-1}$ of lime, respectively. It is the maximum levels that are considered adequate in shoots (Malavolta et al., 1997). Viégas et al. (2012), reported $\mathrm{Ca}$ and $\mathrm{Mg}$ of 9.2 and $2.6 \mathrm{~g} \mathrm{~kg}^{-1}$, 
respectively, in leaf of mahogany seedlings, which is consistent with results of this study. Thus, substrate correction is important during formation of seedling at initial growth of tree. This is occurred by reducing soil acidity, positively influencing the uptake of $\mathrm{N}, \mathrm{P}, \mathrm{Ca}$, and $\mathrm{Mg}$ (Silva et al., 2008; Macedo and Teixeira, 2012), especially when used in substrate composition for production of seedlings in acid soils and deficient in nutrients (Silva et al., 2007).

\section{Macronutrients accumulation in mahogany seedlings}

Accumulation value of macronutrients in shoots of mahogany seedlings (Fig 3) were similar to those observed (Fig 2), with adjustment of quadratic regression equations. Thus, increments provided by limestone were accompanied by increases in SDM (Fig 1d) in same proportion. Silva et al. $(2007,2008)$ observed effect of application of lime rates on accumulation of nutrients in mahogany (Swietenia macrophylla), and kapok (Ceiba pentandra (L.) Gaertn.).

Values of maximum technical efficiency for accumulation of macronutrients, obtained through regression equations showed following descending order in mg plant ${ }^{-1}$ : N $(1653.66)>\mathrm{K}(960.11)>\mathrm{Ca}(330.58)>\mathrm{Mg}(204.95)>\mathrm{P}$ (204.18), provided estimated rates equivalent to $3.12 ; 3.16$; $3.42 ; 2.80$; and $2.74 \mathrm{t} \mathrm{ha}^{-1}$, respectively. Similar results of macronutrient accumulation ( $\mathrm{mg}$ plant $^{-1}$ ) were described by Lima et al. (2015) in Australian red cedar seedlings (Toona ciliata $\mathrm{M}$. Roemer), 140 days after germination, $\mathrm{N}$ (587.7) > $\mathrm{K}$ (64.7) > Ca (30.3) > Mg (13.9) > P (4.3), and Favare et al. (2012) in teak seedlings (Tectona grandis L. f.), 240 days after germination, $\mathrm{N}(1000)>\mathrm{K}(800)>\mathrm{Ca}(500)>\mathrm{Mg}(100)$ $>\mathrm{P}(80)$.

\section{Materials and Methods}

\section{Plant materials}

Mahogany seedlings were transplanted 180 days after germination in experimental field of Embrapa Amazônia Oriental in Belterra city, State of Pará, Brazil. Criteria for selection of seedlings were uniformity of height and root system (Viégas et al., 2014).

\section{Experimental site}

The study was conducted in a greenhouse at Embrapa Amazônia Oriental, Belém city, State of Pará, Brazil (geographic coordinates: $01^{\circ} 26^{\prime} 00^{\prime \prime} \mathrm{S}$ and $48^{\circ} 26^{\prime} 00^{\prime \prime} \mathrm{W}$ ). We used samples of 0-0.2 m layer of a Yellow Alic Latosol medium texture (Embrapa, 2013), collected in area of secondary forest near the site of experiment.

Before application of treatments, a sample substrate was taken for chemical analysis in Soil Laboratory of Embrapa Amazônia Oriental, according to methodology described by Donagema et al. (2011). The soil chemical analyzes the values of nutrients $\left(\mathrm{P}, \mathrm{K}, \mathrm{Ca}\right.$, and $\mathrm{Mg}$ ); $\mathrm{pH}_{\text {water }}$; exchangeable acidity $\left(\mathrm{Al}^{3+}\right)$; and potential $(\mathrm{H}+\mathrm{Al})$ were obtained. Through these data the sum of bases values (SB), cation exchange capacity at $\mathrm{pH} 7.0$ (CEC), base saturation (V\%), and aluminum saturation $(\mathrm{m} \%)$ were calculated (Table 1).

\section{Treatments}

Treatments consisted of five rates of dolomitic limestone $(0$, $0.5,1.9,3.2$, and $\left.4.6 \mathrm{t} \mathrm{ha}^{-1}\right)$ that is calculated based on saturation of $12.4 \%$ (current saturation) as 20, 40, 60 and $80 \%$, with five replications arranged in a randomized design. Limestone rates $($ PRNT $=95 \%)$ were calculated by method of base saturation, from information of initial V\% and CEC at pH7 (Cravo et al., 2007).

\section{Experiment information}

For installation of experiment different amounts of limestone was mixed with the soil. Posteriorly, mixtures were incubated with distilled water for a total period of 30 days in plastic pots with $4 \mathrm{~kg}$ of substrate until the $\mathrm{pH}$ stabilized. Irrigation was performed daily according to mass of water, representing approximately $30 \%$ of mass of the substrate. Two days before transplant, fertilization was done on substrate at rates of 100; 50; 90; 1; 4; and $2 \mathrm{mg} \mathrm{dm}^{-3}$ of N, P, K, Cu, $\mathrm{Zn}$ and $\mathrm{Mn}$, respectively. The pure reagents were used in fertilizer in form of urea; $\mathrm{KH}_{2} \mathrm{PO}_{4} ; \mathrm{KCl} ; \mathrm{CuCl}_{2} \cdot 2 \mathrm{H}_{2} \mathrm{O} ; \mathrm{ZnSO}_{4} \cdot 7 \mathrm{H}_{2} \mathrm{O}$; and $\mathrm{MnCl}_{2} \cdot 4 \mathrm{H}_{2} \mathrm{O}$.

\section{Evaluated characteristics}

At end of experiment, after eight months of transplanting, following variables were evaluated: plant height $(\mathrm{PH})$; stem diameter (SD); root dry matter (RDM); shoot dry matter (SDM); total dry matter (TDM); and shoot/root ratio (SDM/RDM); in addition to concentration and accumulation of $\mathrm{N}, \mathrm{P}, \mathrm{K}, \mathrm{Ca}$, and $\mathrm{Mg}$ in shoot tissues. Plant height corresponded to distance between base of collar and apex of plant, while stem diameter was measured from $0.02 \mathrm{~m}$ height of substrate. Plants were collected, and then shoots and roots were separated. Plant material was washed with distilled water and then dried at $70^{\circ} \mathrm{C}$ to reach a constant mass. After that the biomass was determined with precision scale (Silva et al., 2007; Fernandes et al., 2013). Determination of N, P, $\mathrm{K}, \mathrm{Ca}$, and $\mathrm{Mg}$ followed the methodology described by Malavolta et al. (1997), using middle third of plant leaves. Accumulated amounts of nutrients (mg plant $\left.{ }^{-1}\right)$ were estimated by multiplying nutrient concentrations ( $\mathrm{g} \mathrm{k}^{-1}$ of dry matter) by values of dry matter $\left(\mathrm{g} \mathrm{plant}^{-1}\right)$ and dividing result by one thousand (1000) (Tucci et al., 2009).

\section{Statistical analysis}

The experimental data were subjected to regression analysis using SAEG 9.1 software (Saeg, 2007), isolating plant behavior in response to liming. Regression equations were adjusted for growth variables, uptake and accumulation of nutrients, as dependent variables of limestone.

\section{Conclusion}

Under the conditions of present study, the liming positively influenced uptake and accumulation of $\mathrm{N}, \mathrm{P}, \mathrm{K}, \mathrm{Ca}$, and $\mathrm{Mg}$, with maximum technical efficiency obtained at rates between 2.74 to $3.64 \mathrm{t} \mathrm{ha}^{-1}$ of lime. This shows that the nutritional requirement of plants according to following descending order: $\mathrm{N}>\mathrm{K}>\mathrm{Ca}>\mathrm{Mg}>\mathrm{P}$. The morphological attributes as quality indicators of mahogany seedlings can be achieved with limestone application at rates between 2.74 to $3.64 \mathrm{t} \mathrm{ha}^{-1}$ of lime, being recommended the rates to obtain the greater vegetative development in production of mahogany seedlings in Yellow Alic Latosol.

\section{Acknowledgments}

The authors are grateful to the Grupo de Estudos de Biodiversidade em Plantas Superiores of Universidade Federal Rural da Amazônia (UFRA) for the collaborations of researchers. For Empresa Brasileira de Pesquisa 
Agropecuária (EMBRAPA) - Amazônia Oriental for assistance in field work and all structural support.

\section{References}

Alleoni LRF, Cambri MA, Caires EF, Garbuio FJ (2010) Acidity and aluminum speciation as affected by surface liming in Tropical no-till soils. Soil Sci Soc Am J. 74: 1010-1017.

Arantes SACM, Lavorenti A, Tornisielo VL (2011) Effect of liming on the mineralization of ${ }^{14} \mathrm{C}$-glyphosate in soils. Cienc Agrotec. 35: 234-241.

Araújo RA, Demattê JAM, Garbuio FJ (2009) Application of lime with different reaction degrees: Chemical changes in soil under corn. Rev Bras Ci Solo. 33: 1755-1776.

Artur AG, Cruz MCP, Ferreira ME, Barreto VCM, Yagi R (2007) Cattle manure and liming for guanandi seedlings production. Pesq Agropec Bras. 42: 843-850.

Bernardino CSB, Paiva HN, Neves JCL (2005) Growth and seedling quality of Anadenanthera macrocarpa (Benth.) brenan in response to basis saturation of substratum. Rev Árvore. 29: 863-870.

Camargo MS, Barbosa DS, Resende RH, Korndörfer GH, Pereira HS (2010) Phosphorus in Cerrado soils under liming conditions. Biosci J. 26: 187-194.

Cravo MS, Viégas IJM, Brasil EC (2007) Recomendações de adubação e calagem para o Estado do Pará. Belém, Embrapa Amazônia Oriental. 262p.

Cruz CAF, Paiva HN, Gomes KCO, Guerrero CRA (2004) Effect of different rates of base saturation on the growth and quality of ipê-roxo seedlings (Tabebuia impetiginosa (Mart.) Standley). Sci For. 66: 100-107.

Donagema GK, Campos DVB, Calderano SB, Teixeira WG, Viana JHM (2011) Manual de métodos de análise de solos. $2^{\text {rd }}$ edn. Rio de Janeiro, Embrapa Solos. 230p.

Embrapa (2013) Sistema brasileiro de classificação de solos. $3^{\text {rd }}$ edn. Brasília, Centro Nacional de Pesquisa de Solos. 353p.

Favare LG, Guerrini IA, Backes C (2012) Increasing levels of base saturation and initial development of teak in an Oxisol of medium texture. Ci Fl. 22: 693-702.

Fernandes AR, Paiva HN, Carvalho JG, Miranda JRP (2007) Growth and nutrient absorption in brazilian walnut (Cordia goeldiana huber) seedlings as a function of phosphorus and zinc levels. Rev Árvore. 31: 599-608.

Fernandes AR, Braz AMS, Maia PR, Viégas IJM (2013) Phosphorus fertilization and base saturation in the formation of Swietenia macrophyla seedlings. Rev Ci Agrárias. 56: 261-267.

Gomes KCO, Paiva HN, Neves JCL, Barros NF, Silva SR (2008) Growing of garapa seedling in respond to lime and phosphorus. Rev Árvore. 32: 387-394.

Lima KB, Riter Netto AF, Martins MA, Freitas MSM (2015) Growth, nutrient and total phenols accumulation in australian red cedar seedlings (Toona ciliata) inoculated with mycorrhizal fungi. Ci Fl. 25: 853-862.

Laviola BG, Dias LAS (2008) Nutrient concentration in Jatropha curcas I. leaves and fruits and estimated extraction at harvest. Rev Bras Ci Solo. 32: 1969-1975.

Macedo ST, Teixeira PC (2012) Lime and phosphorus for araza seedling formation. Acta Amaz. 42: 405-412.

Maeda S, Bognola IA (2011) Effect of liming, Gafsa rock phosphate and triple superphosphate in early growth and phosphorus uptake in Eucalyptus dunnii. Pesq Flor Bras. 31: 355-361.
Malavolta E, Vitti GC, Oliveira SA (1997) Avaliação do estado nutricional das plantas: Princípios e aplicações. $2^{\text {rd }}$ edn. Piracicaba, Potafos. 319p.

Marques TCLLSM, Carvalho JG, Lacerda MPC, Mota PEF (2004) Nutrient requirements of Schizolobium amazonicum, Herb. (paricá) seedlings. Cerne. 10: 167-183.

Mauad M, Crusciol CAC, Alvarez RC, Silva RH (2004) Yield of dry matter and nutrient absorption by upland rice cultivars as a consequence of liming. Científica. 32: 178184.

Neves Neto DN, Santos AC, Silva Neto SP (2012) Physical and chemical attributes of soil in ecosiste of Mombaça grass in the eastern Amazon. Rev Ci Agrárias. 55: 75-84.

Novais RF, Alvarez VVH, Barros NF, Fontes RLF, Cantarutti RB, Neves JCL (2007) Fertilidade do solo. Viçosa, Sociedade Brasileira de Ciência do Solo. 1017p.

Pedroso AJS, Silva Júnior ML, Silva GR, Ohashi OS, Birani SM, Leal NC, Melo VS, Teixeira OMMT, Lobato AKS, Oliveira Neto CF, Silva RTL, Ruivo MLP (2012) Influence of liming and boron on development of young Swietenia macrophylla plants grown in Yellow Oxisol. J Food Agric Environ. 10: 1257-1261.

Saeg (2007) Sistemas para Análises Estatísticas, versão 9.1. Viçosa, Fundação Arthur Bernardes.

Santos RA, Tucci CAF, Hara FAS, Silva WG (2008) Phosphated fertilization to produce mahogany seedlings (Swietenia macrophylla King). Acta Amaz. 38: 453-458.

Santos AC, Vilela LC, Barreto PM, Castro JGD, Silva JEC (2010) Changes on chemistry properties by superficial liming and gypsum with of time of collections. Rev Caatinga. 23: 77-83.

Sarcinelli TS, Ribeiro Junior ES, Dias LE, Lynch LS (2004) Symptoms of nutritional deficiency in seedlings of Acacia holosericea submitted to absence of macronutrients. Rev Árvore. 28: 173-181.

Sena JS, Tucci CAF, Lima HN, Hara FAS (2010) Liming effect and correction of the $\mathrm{Ca}$ and $\mathrm{Mg}$ contents of the soil on angelim-pedra (Dinizia excelsa Ducke) seedling growth. Acta Amaz. 40: 309-318.

Silva ARM, Tucci CAF, Lima HN, Figueiredo AF (2007) Growing doses of liming on mahogany (Swietenia macrophylla King) seedling formation. Acta Amaz. 37: 195-200.

Silva ARM, Tucci CAF, Lima HN, Souza PA, Venturin N (2008) Effects of increasing doses of corrective in the formation of sumauma (Ceiba pentandra L. Gaertn) seedlings. Floresta. 38: 265-302.

Silva GR, Silva Júnior ML, Melo VS (2006) Effect of land use and management on chemical properties of a yellow latosol in Pará State, Brazil. Acta Amaz. 36: 151-158.

Silva TAF, Tucci CAF, Santos JZL, Batista IMP, Miranda JF, Souza MM (2011) Liming and fertilization phosphated for the production of Swietenia macrophylla seedlings. Floresta. 41: 459-470.

Souza CAS, Tucci CAF, Silva JF, Ribeiro WO (2010) Nutritional requirements and growth of mahogany (Swietenia macrophylla King) plants. Acta Amaz. 40: 515522.

Tirloni C, Vitorino ACT, Novelino JO, Tirloni D, Coimbra DS (2009) Phosphorus availability due to additions of liming and soil bioactivator. Cienc Agrotec. 33: 977-984.

Tucci CAF, Hara FAS, Freitas RO (2002) Adubação e calagem para a formação de mudas de sumaúma [Ceiba pentandra (L.) Gaertn]. Rev Univers Amaz: Série Cienc Agrárias. 2: 27-39. 
Tucci CAF, Souza PA, Venturin N, Barros JG (2007) Liming and fertilizing for mahogany (Swietenia macrophylla King) seedling formation. Cerne. 13: 299-397.

Tucci CAF, Lima HN, Lessa JF (2009) Nitrogen fertilization in the production of seedlings of mahogany (Swietenia macrophylla King). Acta Amaz. 39: 289-294.

Tucci CAF, Lima HN, Gama AS, Costa HS, Souza PA (2010) Effects of the rising heat in Yellow Oxisoil in the production of silent wood rafts (Ochroma lagopus sw., bombacaceae). Acta Amaz. 40: 543-54.

Vale Júnior JF, Souza MIL, Nascimento PPRR, Cruz DLS (2011) Soils of the Amazon: Etnopedology and sustainable development. Rev Agro@mbiente On-line. 5: 158-165.

Viégas IJM, Lobato AKS, Rodrigues MFS, Cunha RLM, Frazão DAC, Oliveira Neto CF, Conceição HEO, Guedes
EMS, Alves GAR, Silva SP (2012) Visual symptoms and growth parameters linked to deficiency of macronutrients in young Swietenia macrophylla plants. J Food Agric Environ. 10: 937-940.

Viégas IJM, Silva RNP, Silva DAS, Oliveira Neto CF, Conceição HEO, Mascarenhas GS, Okumura RS, Monfort LEF, Silva RTL (2014) Mineral composition and visual symptoms of nutrients deficiencies in curauá plants (Ananas comosus var. erectifolius). Aust J Crop Sci. 8: 747-753.

Walker C, Araújo MM, Maciel CG, Marcuzzo SB (2011) Forest nursery: Technological developments and legislation. Rev Verde. 6: 8-14. 